\title{
Success Criteria in Oil, Gas and Petrochemical Projects
}

\author{
Seyed Hossein Razavi Hajiagha ${ }^{1, *}$, Maryam Shokouhinia ${ }^{2}$ and Shide Sadat Hashemi ${ }^{3}$ \\ ${ }^{1}$ Khatam institute of higher education, Hakin Azam Ave., Shiraz St., Tehran, Iran \\ ${ }^{2}$ Arya Petro Gas Co., No. 14, 8th St., Qaem maqam Ave., Tehran, Iran \\ ${ }^{3}$ Saramadan Andishe Avina Co., Unit 401, No.15, Heyat Ave. North Karegar St., Tehran, Iran \\ *Corresponding author
}

\begin{abstract}
The aim of this paper is to discuss success criteria of oil, gas and petrochemical projects and developing a pattern for evaluation of these projects. It is conducted following a case study approach in which the projects of Arya Petro Gas Co. are examined. The methodological framework of this research includes a literature review for identifying the original success criteria and the factor analysis method is applied on gathered data to develop the considered pattern. Also, the reliability and validity of research tool is examined. Applying the research methodology on gathered data, the developed model showed that the absolute factors for success of oil, gas and petrochemical projects include mutual cooperation of all individuals involved in the project, fulfilling projects' goals, paving the path for future, having clarity of rules and contractors' capability to manage the project.The extended success criteria pattern for oil, gas and petrochemical projects can play a guiding role for managers of project-based companies in this area. These pattern also can be worthy for outsourcing decisions in this field.Identifying success factors provides a critical tool for managers to concentrate their decisions on these factors. Each type of projects in different fields has their own characteristics which made their success factors to be different. Considering this cognitive nature of critical success factors, the main achievement of this study is to extend a pattern of success factors in oil, gas and petrochemical projects for contractor companies.
\end{abstract}

Keywords-function of project; paving the path for future; success criteria of oil, gas and petrochemical projects; Clarity of rules

\section{INTRODUCTION}

Projects play a vital role to find economical flows and direct the organization in project-based organizations and the project manager is the decision maker to offer an approach to conduct the project successfully [1]. Contractor companies are of these project-based organizations which are in charge of making necessary preparations, instituting coordination, performing and fulfilling all related project tasks and they are required to attain their assignments in the framework of all methods, instruction and regulations authenticated by the administrator. In another respect, a project is a transitory attempt to make a product, provide a service or reach a unique result [2].

As Mobey and Parker [3]believed, project-based organization need to achieve a shared and similar viewpoint regarding project success criteria so as to increase the probability of project success so that they can evaluate these criteria orderly and systematically, consider the effects of these criteria and then choose the best approach to obtain such criteria. When these criteria are identified, the success of a project can be desirable. In another view, as Pinto and Prescott [4] have put it, executing projects is complicated which demands considering different and intricate criteria, in the meantime, any projects enjoy their own specific features which is distinguish it from others. Taking these characteristics into account helps the organization to succeed in their projects and disregarding their leads to a fiasco.

Comparing these ideas might suggest that success factors in one project can't be generalized to others due to their unique features and essence, however, project global industrialization share some essential characteristics [5]. Since the projects are complicated and developmental in essence and beneficiaries' purposes and preferences vary in every management level and project cycle, obtaining a general model for project success criteria can play an essential role in decision making and approach determining in project-based organizations.

There have been a number of studies in the respect; however, no unanimous agreement has been made on success criteria because every project demands its own features. In this regard, Lim and Mohamed [6] consider time, cost, quality, function and security on the micro level and satisfaction, benefit and operation on the macro level. Shenhar and Dvir [7]have presented a four dimensional project success model. These four dimensions depend on time. The first dimension includes project operation time to the end of the project. The second dimension can be evaluated a while after project delivery to the employer. The third dimension can be assessed after a considerable time of project operation (1-2 years) and finally the fourth dimension can be judged in 3-4 years after operation. A significant field study has been done by Pinto and Prescott [4]regarding project success. An important achievement of this study was to recognize that essential factors differ during the project cycle. This study has considerably demonstrated workers' factors haven't been of priority in any project cycle from first to third levels.

Andersen et al. [8] have used PCA to survey about different critical success factors of an actual project and extracted nine CSFs. They found that successful project management still depends on "hard features" such as professional planning and cost control, but that "soft skills" such as rich communication and learning from experience are prerequisites for project 
management to achieve superior project success. Lam et al. [9] tried to develop a project success index (PSI) to benchmark the performance of design-build projects from a number of key performance indicators (KPIs). Frödell et al. [10] performed a survey to achieve the opinions of clients against to critical factors in project success. Müller and Jugdev [11]analyzed the popularity of Pinto and his colleagues' contributions to project success and reviewed the development of this field of research since then. They found that the CSFs vary by project types, life cycle phases, industries, nationalities, individuals, and organizations. Nixon et al. [12] have taken an extensive literature review to explore how project leadership performance impacts on project outcomes. Heravi and Ilbeigi [13]used a comprehensive definition of project success consisting of two components: Product success, which deals with the effect of the project's final product; and Project Management success, which focuses upon the project process. Their research includes five steps: identification of the critical performance indices for the twoabove mentioned components; quantification of the performance indices; normalization of the indices; integration of the various performance indices to develop an overall project performance function; and applying the model on a real project in Iran and analyzing the results. Lee and Lee [14] have developed a questionnaire based on previous studies to deal with information success models and adapting them to the open- source EIS (Enterprise Information Systems) context. Saprikis and Vlachopoulou [15] have used Factor analysis and multiple discriminant analysis to investigate the influence of various factors on suppliers' level of use of business-tobusiness (B2B) e-marketplaces by examining three basic variable domains; suppliers' internal environment, their external environment and the characteristics of the adopted B2B e-marketplace. Usman and Callum [16] have used indepth interview to identify, prioritize and categorize the critical success factors (CSFs) for configuration management (CM).

Considering the importance of oil, gas and petrochemical industries to motivate economical growth and put the government's policy for privatization into practice shows the increase of interest in finding out the success criteria in oil, gas and petrochemical projects. Therefore, this research paper investigates the effective factors in success criteria for oil, gas and petrochemical projects and these criteria can evaluate the contractor companies. Following the current studies, this research is a case study to illustrate project success criteria and define them as the following, in an oil, gas and petrochemical contractor company:

1- What are the success criteria in oil, gas, and petrochemical projects for contractor companies?

2- What is the relationship between project success criteria and project characteristics?

3- How can oil, gas and petrochemical projects be evaluated using such criteria?

This paper is organized as follow. The methodological framework of the study is described in the second section. An initial list of critical success factors is identified in and explained in section three. The significance of the identified success criteria on projects are examined in the fourth section.
The developed pattern of success criteria is illustrated in section five. Finally, the paper is concluded in section six.

\section{Methodology}

This current paper is an applied research paper since the obtained results from this paper can make a difference in practical knowledge in management of oil, gas, and petrochemical projects. In addition, since the main goal of this paper is to observe different dimensions of success in oil, gas and petrochemical contractor companies, this paper can be viewed as a descriptive one due to its method to obtain data or the research itself. Relying on various characteristics of this paper, it can be seen as a case study as well and in this respect, the projects in Arya Petro Co. are investigated [17]. The statistical population in this research includes all oil, gas and petrochemical projects in this company. The Factor Analysis method is used to analyze the data. As Costello and Osborne [18] have illustrated in their studies, most studies using Factor Analysis method to analyze their data exercise the ratio of the sample quantity to the number of variables instead of considering a fixed number and this ratio has been less than 5 in $60 \%$ of researches using this method (table 1) so that because this paper includes 20 factors as the number of effective variables on the success of oil, gas and petrochemical projects, the sample volume suits to be 47 (sample volume/the number of variables $=2.35$ ) [18].

TABLE I. THE RATIO OF SAMPLE VOLUME TO THE NUMBER OF VARIABLES IN PRACTICED PAPERS WITH THE FACTOR ANALYSISMETHOD

\begin{tabular}{|c|c|c|}
\hline $\begin{array}{l}\text { Collective } \\
\text { percentage }\end{array}$ & $\begin{array}{l}\text { The number of papers } \\
\text { (percent) }\end{array}$ & $\begin{array}{l}\text { N. of sample volume to } \\
\text { variables }\end{array}$ \\
\hline 35.48 & 35.48 & $\mathrm{~N} / \mathrm{P}<2: 1$ \\
\hline 58.06 & 22.58 & $2: 1<\mathrm{N} / \mathrm{P}<5: 1$ \\
\hline 87.09 & 29.03 & $5: 1<\mathrm{N} / \mathrm{P}<10: 1$ \\
\hline 96.77 & 9.68 & $10: 1<\mathrm{N} / \mathrm{P}<20: 1$ \\
\hline 100 & 3.23 & $20: 1<\mathrm{N} / \mathrm{P}<100: 1$ \\
\hline
\end{tabular}

Random sampling has been used in this research i.e. all projects in Arya Petro Co. enjoy an equivalent chance of selection as a sample. A questionnaire has been used to collect data in this research.

\section{CRITICAL SUCCESS FACTORS IN OIL, GAS, AND PETROCHEMICAL PROJECTS}

Reviewing previous literature on project success criteria, a set of 20 criteria are known, as listed in table 2 along with the references used to identify each criterion.

In the following, all finished Arya Petro Co. projects are studied so as to assign a number to each of these indicators regarding the primary assigned weight. Finally, in order to obtain the weight of each of these indicators in the desirable project, the sum of all the indicator numbers has been gained, the score of each criteria for every project has been received and then obtained number for this project has been divided by the main score of each of these criteria and the result has been multiplied by 100 to figure out the real weight of these criteria in each project. Then Licrit's five-continuum (the least important $0-20 \%$, less $20 \%-40 \%$, medium $40 \%-60 \%$, high $60 \%-80 \%$ and very high $80 \%-100 \%$ ) has been defined and the weight of each criterion for the projects has been recognized. 
TABLE II. PROJECT SUCCESS CRITERIA

\begin{tabular}{|c|c|c|}
\hline No. & $\begin{array}{l}\text { Effective factors on success of oil, gas } \\
\text { and petrochemical projects }\end{array}$ & References \\
\hline 1 & $\begin{array}{l}\text { Making a detailed plan for project } \\
\text { administration at the time of signing the } \\
\text { contract }\end{array}$ & [4] \\
\hline 2 & $\begin{array}{l}\text { Comprehensive and common perception } \\
\text { of the project function among all project } \\
\text { participants (Client, Contractor, } \\
\text { Consultant) }\end{array}$ & [19] \\
\hline 3 & $\begin{array}{l}\text { Providing data on time and making a } \\
\text { suitable communication network for the } \\
\text { involved people }\end{array}$ & {$[4,19]$} \\
\hline 4 & $\begin{array}{l}\text { Establishing a high quality trust among } \\
\text { all project participants }\end{array}$ & {$[4,19]$} \\
\hline 5 & $\begin{array}{l}\text { Solving the problems among project } \\
\text { participants }\end{array}$ & [19] \\
\hline 6 & Cooperation among project participants & {$[19]$} \\
\hline 7 & $\begin{array}{l}\text { Project participants' satisfaction of } \\
\text { project administration during operating } \\
\text { the project }\end{array}$ & {$[7,20,21,22,23]$} \\
\hline 8 & $\begin{array}{l}\text { Contractor's capability to manage the } \\
\text { project }\end{array}$ & {$[4,19,23]$} \\
\hline 9 & $\begin{array}{l}\text { Equipping the contractor with special } \\
\text { and innovative techniques to speed up } \\
\text { project process }\end{array}$ & [19] \\
\hline 10 & Making changes in working area & [19] \\
\hline 11 & $\begin{array}{l}\text { Having a correct risk management by } \\
\text { the contractor }\end{array}$ & {$[22,24]$} \\
\hline 12 & $\begin{array}{l}\text { Participants' satisfaction of the project } \\
\text { outcome }\end{array}$ & {$[6,7,21,23,25,26]$} \\
\hline 13 & $\begin{array}{l}\text { Achieving a logical ratio of investment } \\
\text { return compared to the industry }\end{array}$ & {$[22]$} \\
\hline 14 & $\begin{array}{l}\text { Operating the project based on the } \\
\text { defined budget }\end{array}$ & {$[6,7,21,23,25,26]$} \\
\hline 15 & $\begin{array}{l}\text { Operating the project based on the } \\
\text { estimated time }\end{array}$ & {$[6,7,21,23,25,26]$} \\
\hline 16 & $\begin{array}{l}\text { Administering the project based on } \\
\text { quality and technical specifications }\end{array}$ & {$[6,7,21,23,25,26]$} \\
\hline 17 & $\begin{array}{l}\text { Devoting a bigger market share for the } \\
\text { contractor }\end{array}$ & {$[7]$} \\
\hline 18 & $\begin{array}{l}\text { Establishing new markets for the } \\
\text { contractor }\end{array}$ & {$[7]$} \\
\hline 19 & $\begin{array}{l}\text { Developing new technology for the } \\
\text { contractor }\end{array}$ & [7] \\
\hline 20 & Paving the path for the future & [7] \\
\hline
\end{tabular}

A questionnaire is then designed to gather the information of completed projects. In order to establish the research validity, the questionnaire is sent to the experts in this industry who has got minimum of 10 years experience in oil, gas and petrochemical fields and have had at least five operational projects in these fields. Since there is not much difference between the ideas of these experts-with the aforementioned qualifications- five of them are selected randomly to examine the research validity. The comprehensiveness of all criteria could be proven through the answers of those questions so that the questions explore variables and the study subject precisely based on the experts' ideas. There was an open question at the end of the questionnaire asking these experts to mention any factors which they consider as important characteristic of the projects. They believed that the "kind, value and administration time of projects, the number of involved people, and the record of the project manager" could be accounted for as the characteristics of projects.
Inter-observer reliability method [27] was used to examine the questionnaire external validity in that the questions were weighed simultaneously by an expert with minimum of 10 years experience in oil, gas, and petrochemical projects and 5 operational projects, and the researcher who studied the records of Arya Petro Co.'s projects for 10 finished projects without being aware of the expert's ideas. In this respect, the obtained weights for each criterion by the expert and researcher were compared and the coefficient correlation of variables was studied by SPSS and Pearson's coefficient correlation was achieved which was between 0.94 and $1(0.94<r<1)$. As a result, the questions had an acceptable external reliability i.e. the researcher's ideas in this paper can be used for other projects as well. The research is able to answer the questions for 47 sample projects in the questionnaire due to her accessibility to the documents and being aware of the projects in Arya Petro Gas Co.

For the purpose of finding out the internal reliability of this research, the questions were weighed for 10 projects in Arya Petro Gas Co. by some experts. In this respect, in order to calculate Chronbach's Alpha coefficient, the resulted experts' ideas were analyzed by SPSS software and since the obtained coefficient was $0.807(\alpha=0.807)$ so that the questions in the questionnaire had an acceptable internal reliability and the validity could be confirmed.

\section{DO PROJECT SUCCESS CRITERIA HAVE A SIGNIFICANT IMPACT ON PROJECT SUCCESS?}

Project success criteria have been demonstrated in table 2 using the project success literature and experts' ideas in this industry. These criteria have been firstly extracted and then the relationship between the independent variables, include the record of project manager, type of the project, value of the project, the number of people involved in the project and the project administration time, with each of depended variables listed in table 2 are assessed through Fischer's exact test using SPSS 18. The significance level is considered equal to $5 \%$ in tested hypothesizes.

According to the research findings, there is a significant dependency between the type of the project and the variables of "operating the project based on the defined budget, operating the project based on the estimated time and administering the project based on quality and technical specifications".

On the other hand, there is a dependency between the project duration with the variables of "Making a detailed plan for project administration at the contract signature, providing data on time and making a suitable communication network for the involved people, establishing a high quality trust among all project participants, solving the problems among project participants, cooperation among project participants, project participants' satisfaction of project administration during operating the project, operating the project based on the defined budget, Establishing new markets for the contractor".

There is also a dependency between the variables of the number of people involved in projects and "providing data on time and making a suitable communication network for the involved people, establishing a high quality trust among all 
project participants, solving the problems among project participants, cooperation among project participants, project participants' satisfaction of project administration during operating the project, establishing new markets for the contractor and Paving the path for the future".

There is, moreover, a relationship between the project value and "contractor's capability to manage the project, making changes in working area, having a correct risk management by the contractor, devoting a bigger market share for the contractor, developing new technology for the contractor, establishing new markets for the contractor, paving the path for the future".

It could be observed that there would be a meaningful relationship between the record of the project manager with any of the variables of "making a detailed plan for project administration at the contract signature, comprehensive and common perception of the project function among all project participants (client, contractor, consultant), providing data on time and making a suitable communication network for the involved people, establishing a high quality trust among all project participants, solving the problems among project participants, cooperation among project participants, project participants' satisfaction of project administration during operating the project, contractor's capability to manage the project , participants' satisfaction of the project outcome, operating the project based on the estimated time, achieving a logical ratio of investment return compared to the industry, administering the project based on quality and technical specifications making, operating the project based on the defined budget, devoting a bigger market share for the contractor, paving the path for the future".

\section{CRITICAL SUCCESS FACTORS PATTERN IN OIL, GAS AND PETROCHEMICAL PROJECTS}

As per above section, the relationship between the project characteristics and effective criteria on the project success have been determined. At the next stage, Factor Analysis is used to précis the effective criteria on the project success. For so doing, it should be made sure if the existing data could be applied for the analysis, in other words, if the number of data appropriates the Factor Analysis or not. KMO indicator and Bartlett's test are used for this purpose. The results of KMO indicator and Bartlett's test have been demonstrated in table 3.

TABLE III. KMO INDICATOR AND BARTLETT'S RESULTS

KMO and Bartlett's Test

\begin{tabular}{|c|c|c|}
\hline \multicolumn{2}{|c|}{$\begin{array}{l}\text { Kaiser-Meyer-Olkin Measure of Sampling } \\
\text { Adequacy. }\end{array}$} & .734 \\
\hline $\begin{array}{l}\text { Bartlett's Test of } \\
\text { Sphericity }\end{array}$ & $\begin{array}{l}\text { Approx. Chi-Square } \\
\text { df } \\
\text { Sig. }\end{array}$ & $\begin{array}{r}1336.977 \\
190 \\
.000\end{array}$ \\
\hline
\end{tabular}

As this table shows, the KMO indicator for this research equals 0.734 .

Since this number exceeds 0.6 , the number of samples is enough for the Factor Analysis. In the meantime, Bartlett's test is a necessary condition for the Factor Analysis. In this test, zero hypotheses shows that each variable has correlation with itself. Declining this hypothesis proves that correlation matrix includes meaningful information. Since the amount of Sig. in Bartlett's test is lower than 5\%, Factor Analysis suits this research and the hypothesis of known correlated matrix is declined.

When this assurance to use the data for Factor Analysis is made, coefficient correlation is used to determine how the variables are defined by the extracted factors. As table 4 illustrates, the first column shows initial communalities, and since this column expresses communalities before the extracted factors, all initial communalities equal one.

TABLE IV. COEFFICIENT CORRELATION BETWEEN EXTRACTED FACTORS AND THE EFFECTIVE CRITERIA ON PROJECT SUCCESS

\begin{tabular}{|c|c|c|c|}
\hline No. & $\begin{array}{l}\text { Effective factors on success of } \\
\text { oil, gas and petrochemical } \\
\text { projects }\end{array}$ & $\begin{array}{l}\text { Initial } \\
\text { communalities }\end{array}$ & $\begin{array}{l}\text { Extraction } \\
\text { communalities }\end{array}$ \\
\hline 1 & $\begin{array}{l}\text { Making a detailed plan for } \\
\text { project administration at the } \\
\text { contract signature }\end{array}$ & 1 & 0.938 \\
\hline 2 & $\begin{array}{l}\text { Comprehensive and common } \\
\text { perception of the project function } \\
\text { among all project participants } \\
\text { (employer, contractor, counselor) }\end{array}$ & 1 & 0.934 \\
\hline 3 & $\begin{array}{l}\text { Providing data on time and } \\
\text { making a suitable communication } \\
\text { network for the involved people }\end{array}$ & 1 & 0.96 \\
\hline 4 & $\begin{array}{l}\text { Establishing a high quality trust } \\
\text { among all project participants }\end{array}$ & 1 & 0.91 \\
\hline 5 & $\begin{array}{l}\text { Solving the problems among } \\
\text { project participants }\end{array}$ & 1 & 0.96 \\
\hline 6 & $\begin{array}{l}\text { Cooperation among project } \\
\text { participants }\end{array}$ & 1 & 0.93 \\
\hline 7 & $\begin{array}{l}\text { Project participants' satisfaction } \\
\text { of project administration during } \\
\text { operating the project }\end{array}$ & 1 & 0.921 \\
\hline 8 & $\begin{array}{l}\text { Contractor's capability to manage } \\
\text { the project }\end{array}$ & 1 & 0.897 \\
\hline 9 & $\begin{array}{l}\text { Equipping the contractor with } \\
\text { special and innovative techniques } \\
\text { to speed up project process }\end{array}$ & 1 & 0.903 \\
\hline 10 & Making changes in working area & 1 & 0.976 \\
\hline 11 & $\begin{array}{l}\text { Having a correct risk } \\
\text { management by the contractor }\end{array}$ & 1 & 0.908 \\
\hline 12 & $\begin{array}{l}\text { Participants' satisfaction of the } \\
\text { project outcome }\end{array}$ & 1 & 0.887 \\
\hline 13 & $\begin{array}{l}\text { Achieving a logical ratio of } \\
\text { investment return compared to } \\
\text { the industry }\end{array}$ & 1 & 0.953 \\
\hline 14 & $\begin{array}{l}\text { Operating the project based on } \\
\text { the defined budget }\end{array}$ & 1 & 0.922 \\
\hline 15 & $\begin{array}{l}\text { Operating the project based on } \\
\text { the estimated time }\end{array}$ & 1 & 0.898 \\
\hline 16 & $\begin{array}{l}\text { Operating the project based on } \\
\text { quality and technical } \\
\text { specifications }\end{array}$ & 1 & 0.907 \\
\hline 17 & $\begin{array}{l}\text { Devoting a bigger market share } \\
\text { for the contractor }\end{array}$ & 1 & 0.887 \\
\hline 18 & $\begin{array}{l}\text { Establishing new markets for the } \\
\text { contractor }\end{array}$ & 1 & 0.891 \\
\hline 19 & $\begin{array}{l}\text { Developing new technology for } \\
\text { the contractor }\end{array}$ & 1 & 0.894 \\
\hline 20 & Paving the path for the future & 1 & 0.904 \\
\hline
\end{tabular}

The second column shows the extraction communalities. The larger the amount of extraction communalities, the better is 
the emergence of extracted factors of variables. Since the amount of extraction communalities is larger than 0.5 , all extracted factor have a high correlation coefficient with variables and they all can define the research variables.

Factor Analysis calculates the determined variance of each of factors so that as the research shows only the first five factors can explain approximately $92 \%$ of variance of variables; therefore, these five factors are maintained in the analysis and the others are eliminated (table 5).

In the next step, Factor Analysis results are investigated by analyzing the main factors. This method helps to state the weight of each factor of the success criteria of oil, gas and petrochemical projects on all factors, but since the meaning of each factor can be defined after rotation process, then should be a factor rotation first. In addition, the rotated factors show more precise correlations than un-rotated ones. This rotation changes the factor weights and their meanings to the analytical method of main elements. The results of factor matrix have been demonstrated in tables 6 after their rotation.
TABLE V. VARIANCE DETERMINED BY THE ANALYSIS OF MAIN FACTORS

\begin{tabular}{|c|c|c|c|}
\hline Factor & Variance & $\begin{array}{c}\text { Variance } \\
\text { percentage }\end{array}$ & $\begin{array}{c}\text { Collective } \\
\text { variance } \\
\text { percentage }\end{array}$ \\
\hline 1 & 6.981 & 34.903 & 34.903 \\
\hline 2 & 4.819 & 24.094 & 58.997 \\
\hline 3 & 2.886 & 14.432 & 73.428 \\
\hline 4 & 2.085 & 10.427 & 83.855 \\
\hline 5 & 1.611 & 8.056 & 91.91 \\
\hline 6 & 0.329 & 1.645 & 93.556 \\
\hline 7 & 0.267 & 1.337 & 94.893 \\
\hline 8 & 0.196 & 0.978 & 95.87 \\
\hline 9 & 0.163 & 0.815 & 96.685 \\
\hline 10 & 0.151 & 0.757 & 97.442 \\
\hline 11 & 0.11 & 0.552 & 97.995 \\
\hline 12 & 0.095 & 0.475 & 98.469 \\
\hline 13 & 0.082 & 0.412 & 98.881 \\
\hline 14 & 0.072 & 0.359 & 99.24 \\
\hline 15 & 0.043 & 0.217 & 99.457 \\
\hline 16 & 0.04 & 0.202 & 99.66 \\
\hline 17 & 0.027 & 0.134 & 99.793 \\
\hline 18 & 0.019 & 0.094 & 99.888 \\
\hline 19 & 0.015 & 0.077 & 97.965 \\
\hline 20 & 0.007 & 0.035 & 100 \\
\hline & & & \\
\hline
\end{tabular}

TABLE VI. FACTOR MATRIX RESULTS AFTER ROTATION

\begin{tabular}{|c|c|c|c|c|c|c|}
\hline No & Effective factors on success of oil, gas and petrochemical projects & Factor1 & Factor2 & Factor3 & Factor4 & Factor5 \\
\hline 1 & Providing data on time and making a suitable communication network for the involved people & 0.931 & -0.099 & 0.18 & 0.175 & 0.14 \\
\hline 2 & Cooperation among project participants & 0.923 & -0.078 & 0.155 & 0.157 & 0.153 \\
\hline 3 & Solving the problems among project participants & 0.922 & -0.072 & 0.163 & 0.186 & 0.211 \\
\hline 4 & Establishing a high quality trust among all project participants & 0.914 & -0.043 & 0.172 & 0.111 & 0.176 \\
\hline 5 & Project participants' satisfaction of project administration during operating the project & 0.899 & -0.019 & 0.178 & 0.164 & 0.223 \\
\hline 6 & Achieving a logical ratio of investment return compared to the industry & -0.108 & 0.964 & 0.056 & 0.046 & 0.82 \\
\hline 7 & Operating the project based on the defined budget & -0.082 & 0.956 & 0.03 & 0.02 & 0.02 \\
\hline 9 & Operating the project based on the estimated time & -0.106 & 0.935 & 0.079 & -0.036 & 0.068 \\
\hline 10 & Participants' satisfaction of the project outcome & 0.059 & 0.934 & 0.105 & 0.27 & -0.013 \\
\hline 11 & Developing new technology for the contractor & 0.118 & 0.094 & 0.933 & 0.33 & 0.2 \\
\hline 12 & Devoting a bigger market share for the contractor & 0.112 & 0.35 & 0.932 & -0.22 & 0.71 \\
\hline 13 & Paving the path for the future & 0.229 & 0.105 & 0.906 & 0.029 & 0.136 \\
\hline 14 & Establishing new markets for the contractor & 0.259 & 0.141 & 0.894 & 0.074 & -0.12 \\
\hline 15 & Making changes in working area & 0.189 & 0.046 & 0.21 & 0.965 & 0.084 \\
\hline 16 & Comprehensive and common perception of the project function among all project participants & 0.171 & 0.049 & 0.026 & 0.946 & 0.082 \\
\hline 18 & Equipping the contractor with special and innovative techniques to speed up project process & 0.188 & -0.026 & 0.126 & 0.045 & 0.921 \\
\hline 19 & Contractor's capability to manage the project & 0.226 & 0.095 & 0.07 & 0.15 & 0.902 \\
\hline 20 & Having a correct risk management by the contractor & 0.299 & 0.05 & 0.055 & 0.1 & 0.896 \\
\hline
\end{tabular}

When factor rotation ends, each of five effective factors on project success should be given a name which umbrellas all the involved criteria. Therefore, regarding the nature of all criteria, the following general terms have been presented for the project success.

TABLE VII. FINAL EFFECTIVE FACTORS ON THE SUCCESS OF OIL, GAS AND PETROCHEMICAL PROJECTS

\begin{tabular}{|l|l|}
\hline No. & $\begin{array}{l}\text { Final effective factors on the success of oil, gas and } \\
\text { petrochemical projects }\end{array}$ \\
\hline 1 & Mutual cooperation among all involved in project \\
\hline 2 & Achieving the desired function of the project \\
\hline 3 & Paving the path for the future \\
\hline 4 & Clarity of all approaches and regulations \\
\hline 5 & Contractor's capability to manage the project \\
\hline
\end{tabular}

Regarding the results, Factor Analysis can be used as a model to evaluate oil, gas and petrochemical projects respecting the research findings. This pattern has been illustrated in figure 1.

\section{CONCLUSION}

Project-based organizations are dstiguished from other organizatons on the ground of their structural features which make them operate different projects simultaneously. Contractor companies are an instance of such organizations which are responsible for preparation, coordination, administration and finishing all project.Their related tasks and duties should be accomplished in a framework of methods, regulations and instructions confirmed by an administrator. On 
the other hand, a project is a temporary attempt to creat a product, provide a service or achieve a unique result.

In project-base organizations detreming a pattern to identify project success criteria sounds essentional and imperative because these organizations can then figure out their actual function and afterwards it will enable them to improve their function in the future.

The present research paper is to answer the following question:

1- What are the success criteria in oil, gas, and petrochemical contractor companies?

2- What is the relationship between project success criteria and project characteristics?

3- How can oil, gas and petrochemical projects be evaluated using such criteria?

In order to answer the aforementioned questions, project success criteria are identified by the relevant literature and then they are presented as 20 criteria to assess project success and a questionnaire is designed for that purpose. The reliability of the research tools has been confirmed by the experts in this industry. Inter-observers validity was used to investigate the external reliability and since Pearson's correlation coefficient for the researched variables is between 0.94 and $1(0.94<\mathrm{r}<1)$, the questionnaire enjoyed an acceptable external reliability i.e. the researcher's ideas can be generalized for other projects and because the researcher is able to access Arya Petro Gas Co. documents and is well familiar with this company's projects, she has been able to answer the questions for 47 sample projects. The obtained Chronback Alpha coefficient is 0.807 $(\alpha=0.807)$ which means that the questionnaire possess an acceptable internal validity. Following the extraction of 20 mentioned criteria, Factor Analysis is used to categorize these criteria into five main groups depending on their priority and each of them has been given a name by the researcher. The final model showed that the absolute factors for success of oil, gas and petrochemical projects include mutual cooperation of all individuals involved in the project, fulfilling projects' goals, paving the path for future, having clarity of rules and contractors' capability to manage the project. Following suggestions are made based on the research findings:

1- Identifying appropriate approaches to increase the cooperation of involved participants in the project (Client, Contractor and Consultant)

2- Identifying and investigating the effects of changes on the scope of work on the project outcome and presenting some approaches to decrease negative effects on the participants

Identifying and investigating the effects of vagueness in regulations and approaches on the project expected results and addressing new approaches to reduce these negative effects on the involved people in the project.

\section{REFERENCES}

[1] C.W.Kuen, S. Zailani and Y. Fernando, Critical factors influencing the project success amongst manufacturing companies in Malaysia, Afr. J.
Bus. Manage. 3(2009) 16-27.

[2] Project Management Institute, A Guide to Project Management Body of Knowledge, Project Management Institute Inc.,Pennsylvania, 2004.

[3] A. Mobey, D. Parker, Risk evaluation and its importance to project implementation, Int. J. Prod. Perform. Manage. 51(2002) 202 - 208.

[4] J.K. Pinto, J.E. Prescott, Variation in critical success factors over the stages in project life cycle, J. Manage. 14(1988) 5-18.

[5] F.T.T. Phua, S. Rowlinson, How important is cooperation to construction project success? A grounded empirical quantification, Eng. Constr. Archit.Manage. 11(2004) 45-54.

[6] C.S. Lim,M.Z. Mohamed, Criteria of project success: an exploratory reexamination, Int. J. Proj. Manage. 17(1999) 243-248.

[7] A.J. Shenhar, D. Dvir, Toward a typological theory of project management, Res.Policy. 25(1996) 607-632.

[8] E.S.Andersen, D.Birchall, S.A.Jessen andA.H. Money, Exploring project success,Baltic J. Manage. 1 (2006) 127- 147.

[9] E.W.M.,Lam, A.P.C. Chan and D.W.M. Chan, Benchmarking the performance of design-build projects: Development of project success index, Benchmarking: An Int. J. 14(2007) 624-638.

[10] M. Frödell,P.E. Josephson and G. Lindahl, Swedish construction clients' views on project success and measuring performance, J. Eng. Des. Technol. 6(2008) 21-32.

[11] R. Müller, K. Jugdev, Critical success factors in projects: Pinto, Slevin, and Prescott - the elucidation of project success, Int. J. Managing. Proj. Bus. 5 (2012) $757-775$

[12] P.Nixon, M. Harrington and D. Parker, Leadership performance is significant to project success or failure: a critical analysis, Int. J. Prod. Perform. Manage. 61(2012) 204-216.

[13] G. Heravi, M. Ilbeigi, Development of a comprehensive model for construction project success evaluation by contractors, Eng. Constr. Archit. Manage. 19(2012) 526-542.

[14] S.M.Lee, S.H. Lee, Success factors of open-source enterprise information systems development, Ind. Manage. Data. Syst. 112 (2012) 1065-1084.

[15] V. Saprikis, M. Vlachopoulou, Determinants of suppliers' level of use of B2B e-marketplaces, Ind. Manage. Data. Syst. 112 (2012) 619-643.

[16] A. Usman, K. Callum, Critical success factors for configuration management implementation, Ind. Manage. Data. Syst. 113 (2013) 250264.

[17] U. Sekaran, R. Bougie, Research Methods For Business: A Skill Building Approach, John Wiley \& Sons, West Sussex, 2006.

[18] A.B. Costello, J.W. Osborne, Best practices in exploratory factor analysis: Four recommendations for getting the most from your analysis, Pract. Assesst. Res. Eval. 10 (2005) 1-9.

[19] A.Chan,D. Ho and C. Tam, Design and Build Project Success Factors: Multivariate Analysis, J. Constr. Eng. Manage. 127(2001) 93-100.

[20] W.H. Delone, E.R.McLean, Information System Success: The Quest for the Dependent Variable, Inform. Syst. Res. 3 (1992) 60-95.

[21] J.Wateridge, How can IT/IS Projects be Measured for Success?, Int. J. Proj. Manage. 16(1998) 59-63.

[22] H.Brydoy, Water house, Project Success Criteria , on http://www.scandoil.com

[23] J.R.Turner, The Handbook of Project-Based Management: leading strategic change in organizations, McGraw-Hill, New York, 2008.

[24] W. Briner, C. Hastingsand M.Geddes, Project Leadership, Hampshire, Gower Publishing, (1996).

[25] D. White, J. Fortune, Current practice in project management - an empirical study, Int. J. Proj. manage. 20(2002) 1-11.

[26] H. Kerzner, Project Management: A system approach to planning,scheduling, and Controlling, John Wiley \& Sons, New Jersey, 2013.

[27] M.S. Litwin, How to Measure Survey Reliability and Validity, Sage Publications, California, 1995. 


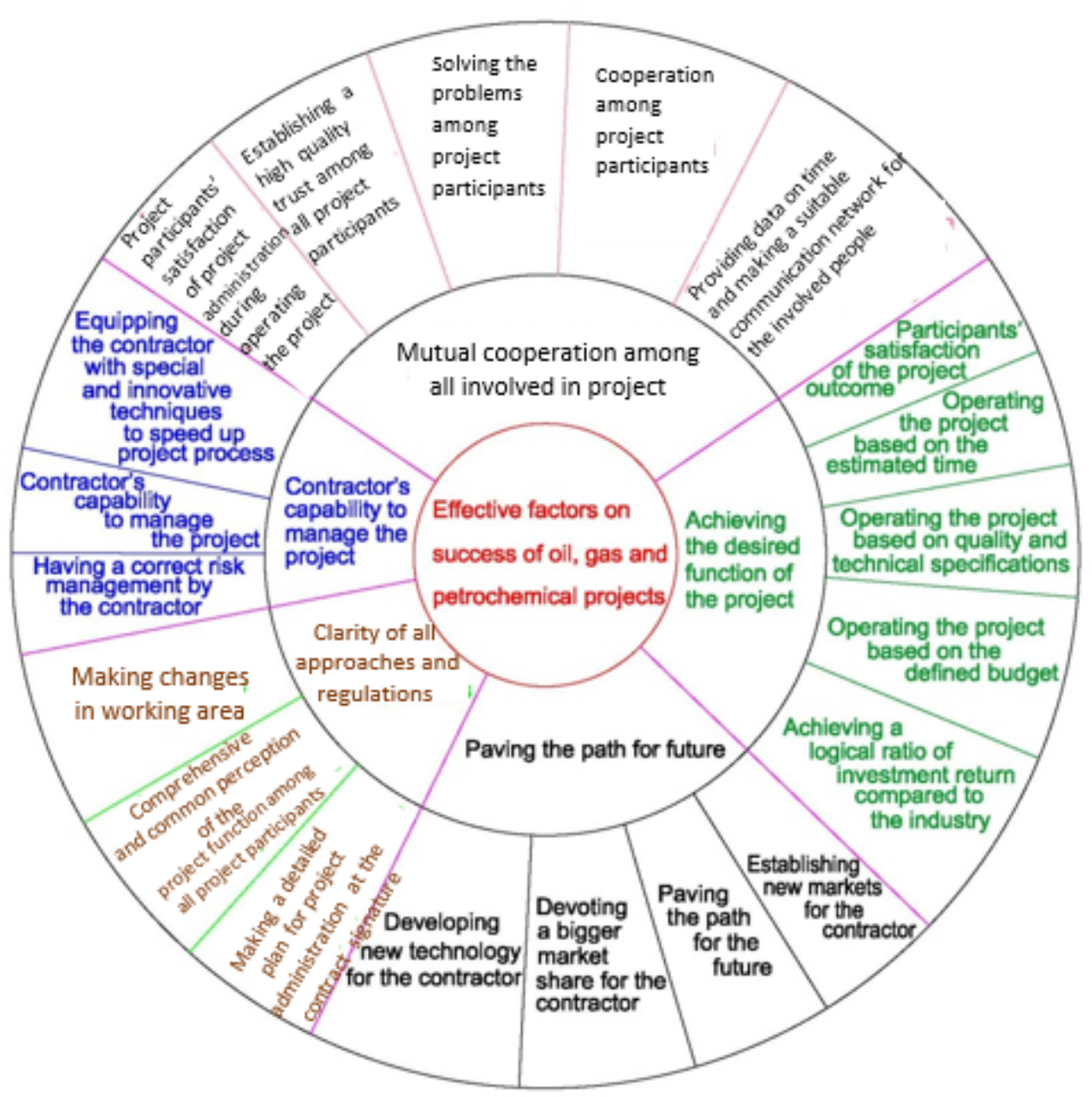

FIGURE I. A PATTERN TO EVALUATE THE OIL, GAS AND PETROCHEMICAL PROJECTS 